\title{
The New Apostolic Reformation: The critical reflections of the ecclesiology of Charles Peter Wagner
}

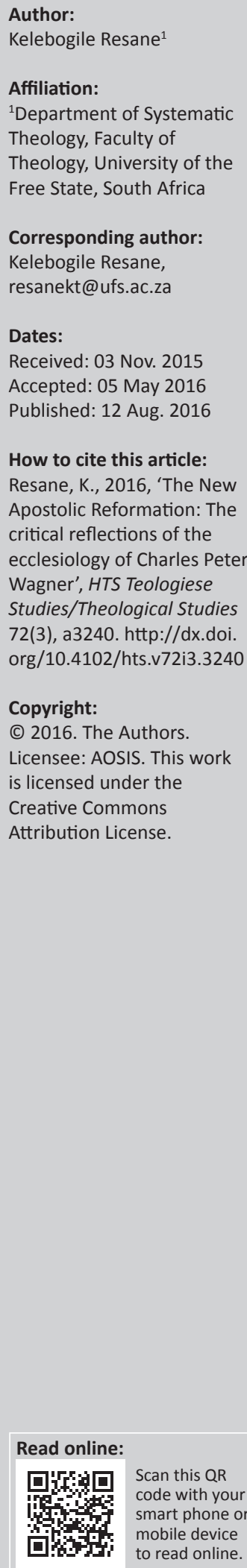

Charles Peter Wagner is a well-known missiologist and ecclesiologist of the latest era. He is the author, trainer and prayer warrior who founded the New Apostolic Reformation (NAR) that seeks to establish a fourth house. The NAR is a heterodox movement in Protestant Christianity sometimes known as the apostolic-prophetic movement, commonly associated with both the Pentecostal and Charismatic churches worldwide since the beginnings of the 1990s. Central to their theology is their locus of dogma that the task of the church, under the leadership of the apostles and prophets, is to take dominion of the earth within Christendom (distinct from Catholicism, Protestantism and Orthodox Christianity). The ekklesia is the people of God, whether they are gathered in their congregations on Sunday as the nuclear Church, or scattered in the workplace Monday through Saturday as the extended Church. The extended Church, just like the nuclear Church, is founded on apostles and prophets, but in the extended Church these are the different people who operate differently under a different rule book. It is these extended church leaders who will be most effective in transforming society. Workplace apostles are called to take dominion in business, government, arts and entertainment, media, family and education. Panoramically, Wagner's ecclesiology, like mainstream evangelical ecclesiology, is trinitarian, communal, missiological and eschatological in nature and character. The weaknesses on his ecclesiology include the notions of polity based on fivefold ministries, balance of power and authority on church leadership, phenomenological approach to texts, exegetical shortcomings, and secular models in ecclesiastical governance.

\section{Background and introduction}

Charles Peter Wagner was born in 1933. He is undoubtedly a theologian, missiologist, missionary writer, teacher, and church growth specialist best known for his controversial writings on spiritual warfare. He served as a missionary in Bolivia under the ministry of South American Mission and Andes Evangelical Mission, which is now Society of International Missions (SIM) between 1956 and 1971. He served as a professor of Church Growth at Fuller Theological Seminary's School of World Missions from 1971 and retired in 2001. From 1993 to 2011, he served as the president of Global Harvest Ministries. His current involvement is being a chancellor emeritus of Wagner Leadership Institute, training leaders for New Apostolic Reformation (NAR). He also serves as the vice president of Global Spheres, Inc. Wagner is internationally credited for founding the NAR, a movement associated with Texas Governor, Rick Perry, made famous by an evangelical Christian prayer vigil in Houston's Reliant Stadium on 6 August 2011 (Wilder 2011b). The focus of this article takes it from here - the ecclesiology of C Peter Wagner.

Wagner coined a term the 'New Apostolic Reformation' to describe a movement that seeks to establish a fourth house within Christendom (distinct from Catholicism, Protestantism and Orthodox Christianity). In my doctoral thesis, I have coined the title, Emerging Apostolic Movement to refer to this phenomenon in a broader sense. The NAR is largely associated with the Pentecostal and the Charismatic movements. Its distinctiveness from the classical Pentecostal or Charismatic movement is its dogmatic assertion of the fivefold ministry (Ephesians 4:11) as the governance of the church; with special emphasis on offices of prophet and apostle (Wagner 2013). The movement engages aggressive recruitment of pastors, independent congregations and nondenominational churches by assimilating them through cell group meetings, church planting and rapid cytokinesis. The assimilation processes articulate into the formation or membership into some form of loose network with a tightly knit history that serves as a basis of an informal or unadvertised governmental structure. Through this process, it expects to rapidly overwhelm and dominate the pre-existing Christian denominations of the world. 


\section{His works}

Wagner authored more than 70 books. He became famous in the 1970s as a champion for the church growth movement that took North America and other parts of the world by storm. The writing that made him famous was Confronting the Powers: How the New Testament Church Experienced the Power of Strategic-Level Spiritual Warfare and Engaging the Enemy (1996). In this monograph, Wagner expanded the subject of spiritual warfare. He breaks down spiritual warfare into three levels:

- Ground Level: Person-to-person, praying for each other's personal needs

- Occult Level: Deals with demonic forces released through activities related to Satanism, witchcraft, astrology and various forms of occultism

- Strategic Level or Cosmic Level: To bind and bring down spiritual principalities and powers that rule over governments. This is when one praying uses spiritual mapping and tearing down strongholds to engage in spiritual warfare against territorial spirits.

Wagner (2006:39-40) indicates elsewhere that for many years he taught the Reformed doctrine of sanctification until he started to be involved in teaching and practicing spiritual warfare. The interaction with Cindy Jacobs conscientised him to the issue of spiritual warfare.

In his other monograph, Engaging the Enemy (1991), Wagner claims that Christians or church in general had been ignorant on these methods until the early 1990s. The bottom line of his argument is that Satan and his demons are literally active and alive in the world. Satan's territorial spirit-demons can be identified by names, and Christians are to engage in spiritual warfare with them.

Wagner furthers his theology in another work, Hard-Core Idolatry: Facing the Facts (2001) to assert that Catholic saints bring honour to the spirits of darkness, and promotes the burning of their statues in Argentina It can also be observed that extra-biblical revelation also plays some role in Wagner's theology in general. For instance, he asserts that the Holy Spirit came to his famous associate known as Cindy Jacobs, who is a 'prophet' in Wagner's Apostolic Council of Prophetic Elders; that the Argentinean city of Resistencia must be confronted with the burning of idols; just like the magicians did in Ephesus (2001:38-40).

\section{The books that inform us of his ecclesiology}

Your Spiritual Gifts can Help Your Church Grow (1994/2005): In this book, Wagner elaborates the importance of the gifts of the Spirit in the evangelistic and missionary tasks of the church. He dwells on the fact that the ministry of the church must be placed back to the hands of the believers.

The New Apostolic Churches (1998): Together with the other NAR member contributors, they try in this book to rediscover the New Testament models of church leadership, based on the fivefold ministries.
Churchquake (1999): Wagner writes about a revolution taking place in the Church - an extraordinary work of God that is changing the shape of Christianity around the world. The NAR is a grassroots phenomenon in which God is raising up alliances of non-denominational churches and leaders worldwide to help fulfil the last awesome push for the Great Commission. Wagner identifies and examines present-day apostolic church networks that are bound together not by doctrine or tradition, but by shared passion for local and worldwide evangelism, energetic worship, fervent prayer and church planting.

Changing Church (2004): Wagner tells readers exactly how they can contribute to the Church's worldwide fulfilment of God's kingdom on earth! The Changing Church sheds light on the exciting things that are happening by the power of the Holy Spirit! The Church is being aligned with God's plan for the Great Harvest. Although we might feel small in the scheme of things, we can make a huge impact when we unite with what God is doing worldwide. This new vision overlooks denominational barriers, asking one and all to join together for the ultimate fulfilment of God's purposes.

Apostles Today (2006): Transformation of the city was the battle cry in the 1990s. How far have we come since then? How do apostles fit into the urban landscape? How do they line up with God's plans? Wagner has been writing on these subjects for a number of years, and now he brings city transformation and the role of apostles together in one volume. This book is a call for apostles to assume their rightful sphere of authority to see God's will accomplished here on earth. Wagner relates his decades of experiences and those of others, showing the role of apostles not only in the traditional church, but also in the extended church. Apostles Today offers vision for the role of apostles in healthy churches, workplaces and cities.

Dominion!: How Kingdom Action Can Change the World (2008): Jesus has mandated his church to actively engage in transforming society on earth - 'Thy kingdom come on earth as it is in heaven'. But when societal issues and problems loom large, it can seem an impossible task. Offering solid teachings on apostles and prophets, spiritual warfare, the church in the workplace, and much more, Wagner shows readers just how kingdom action can change the world. With a sense of mission and urgency, he explores the biblical roots of dominion theology, the views of great Christian thinkers through the ages, the ways Christians are working it out in their lives and on the job, and what each part can do when brought together through the operational power of the Holy Spirit.

\section{The New Apostolic Reformation theological perspectives}

The NAR is a heterodox movement in Protestant Christianity sometimes known as the apostolic-prophetic movement, commonly associated with both the Pentecostal and Charismatic churches worldwide since the beginnings of 
the 1990s. Central to their theology is their locus of dogma that the task of the church, under the leadership of the apostles and prophets, is to take dominion of the earth. God originally gave humanity dominion of the earth. This dominion was lost at the fall. Since that time, God has been seeking a people to reclaim that lost dominion. Christ's death on the cross and victory over Satan made the task of retaking dominion possible.

Dominion theology provides the biblical paradigm for understanding how the Church must involve itself in the cultural mandate as well as the evangelistic mandate. God's soteriological goal is not only the salvation of souls, but also the social transformation. The theme of dominion emanates from Genesis 1:26 and pervades through the Bible. In some instances, Wagner and his disciples speak of dominion as Kingdom theology. They insist that God's will can be accomplished on earth when people become empowered by the Holy Spirit and move into action. In a nutshell, the following doctrinal statements permeate the movement's doctrinal assumptions or criteria:

The individual believer: There is a direct revelation of Christ to each believer that may come through prophecy or miracles such as healing.

The Holy Spirit: Some critical reflection suffices that NAR is descriptive of a theological movement and is not an organisation and therefore does not have formal membership. The members of the movement are diverse in their beliefs, as some hold to their denominational interpretations of the active ministry of the Holy Spirit within individual believers.

The Church: The church is the true body of saved believers. However the church must be governed by the fivefold ministries of Ephesians 4:11. The majority of the member churches have active ministries of spiritual warfare (Wagner 2000). In some instances, Wagner defends the movement as orthodox in faith and confessionally in line with the Apostles' Creed. He has listed the differences between the NAR and traditional Protestantism as follows (2011):

- Apostolic governance: The Apostle Paul's assertion that Jesus appoints apostles within his church continues to this day.

- The office of the prophet: There is within the church a role and function for present-day prophets.

- Dominionism: 'When Jesus came, He brought the kingdom of God and He expects His kingdom-minded people to take whatever action is needed to push back the long-standing kingdom of Satan and bring the peace and prosperity of His kingdom here on earth' (Wilder 2011a).

- Theocracy: Not to be confused with theocratic government but rather the goal to have 'kingdom-minded people' in all areas of society. There are seven areas identified specifically: religion, family, education, government, media, arts \& entertainment, and business (Wilder 2011a).

- Extra-biblical revelation: There is available to all believers the ability to hear from God. The one major rule governing any new revelation from God is that it cannot contradict what has already been written in the Bible. It may supplement it, however.

- Supernatural signs and wonders: Signs and wonders such as healing, demonic deliverance and confirmed prophecies accompany the move of God.

- Relational structures: church governance has no formal structure but rather is by relational and voluntary alignment to apostles.

\section{Summary of Wagner's ecclesiology}

In another book; Dominion!: How Kingdom Action Can Change the World (2008); Wagner presents the basic tenets of his ecclesiology. He starts by pointing out that the kingdom of God is not confined to the four walls of the church. The ekklesia is the people of God, whether they are gathered in their congregations on Sunday as the nuclear Church, or whether they are scattered in the workplace Monday through Saturday as the extended Church. The extended Church, just like the nuclear Church, is founded on apostles and prophets, but in the extended Church these are the different people who operate differently under a different rule book. However, it is these extended church leaders who will be most effective in transforming society. Workplace apostles are called to take dominion in business, government, arts and entertainment, media, family and education. Panoramically, Wagner's ecclesiology, like mainstream evangelical ecclesiology, is trinitarian, communal, missiological and eschatological in nature and character.

\section{Reasons for rejection of Wagner's approach Wagner's polity is based on the fivefold ministry of Ephesians 4:11-13}

There is no doubt, Wagner's theology, especially ecclesiology has moved dramatically from the traditional Protestant polity of either congregational, Presbyterial or Episcopalian structures. Throughout his career, Wagner emphasises the fivefold ministry of Ephesians 4:11-13 as God's divine structure for the church. In 2006 he published a book titled Apostles Today. In this book, he promotes the role of these fivefold ministries with a special reference to the 'apostle':

In traditional denominations, the locus of authority is ordinarily found in groups, not in individuals. That is why we are accustomed to hearing about deacon boards, boards of trustees, presbyteries, general assemblies and so on. In the New Apostolic Reformation, however, trust has shifted from groups to individuals. On the local church level, the pastor now functions as the leader of the church instead of as an employee of the church. On the translocal level, the apostle is the one who has earned the trust of the pastors and other leaders; and trust inevitably imparts authority (Wagner 2006:23).

Wagner's conviction is that the apostle in the twenty-first century 'is not self-appointed or elected by any ecclesiastical body, but is chosen by the Lord Himself' (2006:17). The apostle is pivotal to NAR. They lay foundations for social transformation 
and give direction to the church. They cast vision and formulate the mission for the church. Each of the five offices is uniquely located in the church for cultural transformation, for as far as Wagner is concerned, Christ's mandate to the church is both evangelistic and cultural. According to Wagner, the apostles possess a spiritual gift, assignment or a call, extraordinary character, followers and a vision. He furthermore attests that apostles are characterised by activities such as receiving revelation, casting a vision, giving birth (pioneering), imparting blessings to others, governing by setting systems in order, teaching, sending off, finishing God's project or season to desired conclusion, leading the church in spiritual warfare, aligning generations, and finally equipping. All these apostolic characteristics and functions are common in Wagner's books, especially in Apostles Today.

The fivefold ministry as capsulated in Ephesians 4 passage is open to debate. Is it a precursor for church structure and government, or is it a reflection of the pneumatic community in action? The wisdom of Kreitzer (1997:129) is called upon for the hypotheses that the fivefold ministry is not a theologically legitimate church government to be applied to the 21st century church:

It is unwise to view the five categories of people here listed as evidence of the prevailing ecclesiastical structures of the time, or to take them as an indication of the situation of the church to which the Writer directs his letter. Likewise, it is not at all clear that what is intended here is a hard and fast distinction between the clergy and laity, as the insertion of a comma between the phrases 'to equip the saints' and 'for work in his service' in some translations of verse 12 suggests. One must look elsewhere, such as the Pastoral Epistles, to substantiate a theology of the twofold office of Christian ministers, since ecclesiastical legitimisation of the forms of an ordained ministry is not the writer's focus here. (Kreitzer 1997:129)

The Lord shows how His love and grace must be administered in His Church. The missional church that He leaves behind is endowed with gifts in order to strengthen and expand itself. The passage points to the existence in the church of those whose task is to specifically move the church towards the goal of maturity in Christ.

These are the gifts that are sovereignly distributed to the members of the body, which is the church - an instrument for carrying out God's purposes in the cosmos. In Ephesians 4:11, these are the gifts of ascended Christ to the church. These gifts are the persons themselves not the abilities or the energies as is found in the charismata of 1 Corinthians 12:4-11. These gifts are released for the church to function as it should. The gifts are deliberately released for the edification of the body (4:12), for the avoidance of false teaching (4:14). They are Christ's ministries that reflect His victory by which $\mathrm{He}$ endows the church.

\section{The balance of power and authority}

Authority does not exist in a vacuum. All forms of authority find their raison d'etre in the context of a particular community and in relation to the specific goals of that community.
The historical overview of the fivefold ministry shows that the NAR holds to the fact that the structure of the church is controlled through potestas sacra, holy power, balanced with authority by the apostolic figures. There are two symbiotic terms related to Charismatic leadership of the church. These are power (dunamis) and authority (exousia). There is also another term, influence. Dunamis occurs about 118 times in the New Testament (Kraft 2000:67). The Pauline usage of the word is applied more frequently, than as do the Gospels writers. It is the normal word for power, might, strength or force, and is often used in the plural to refer to miracles (wonders) in the phrase miracles and wonders (Acts 2:22; 2 Corinthians 12:12; Hebrews 2:4). It is also encountered in reference to supernatural beings (Romans 8:38; 1 Corinthians 15:24; Ephesians 1:21; 1 Peter 3:22). The power of God is ordinarily referred to as dunamis, as is the power Jesus gives to disciples (Luke 9:1). The earthly power attached to rulers, armies or weather, was also labelled dunamis.

Exousia is the classical New Testament Greek term referring to the ability to perform an action to the extent that there are no obstacles in the way. It focuses on the right to use power rather than on the power itself. It is the right to do something granted by a higher authority. The word is found 108 times in the New Testament (Kraft 2000:67), and always used in relation to people. 'It is a personal right, either because of status or by delegation, to assert power, whether in legal, political, social, or moral ways in the human world or in the spiritual realm' (Kraft 2000:67). In the Greek Old Testament (LXX), exousia means right, authority, or permission, the legal or political freedom to act. Paul Avis (1992:19) expresses New Testament usage of exousia: 'When applied to Jesus Christ it denotes his divinely given dominion and status (Matt 28:18: "All exousia in heaven and on earth has been given to me"). Exousia is ultimately divine authority (Mark 2:10: "the Son of man has exousia on earth to forgive sins"). Exousia is the right that lies behind the exercise of power (dynamis), though the two terms are sometimes used almost synonymously'. Exousia legitimates dunamis.

It is on this basis that the NAR leaders claim the authority that they should exercise on their subjects. Though the 'authority' concept seems to be theologically sound, it can be abused and displaced from its biblical intentions. Kraft (2000) warns sternly:

In the New Testament, both power (dunamis) and authority (exousia) flow from the work of Christ, first as He employed them and then as He empowers His followers to do His works... Thus, the authority we participate in is that modelled by Jesus Himself and grounded, as it was with Jesus, in the same power of the Holy Spirit. It is the God-given right to receive and use God's power that flows from the indwelling Holy Spirit. (p. 67)

In researching the NAR, one realises that power is the influence which involves people's emotions, cognitions, motivations and behaviours. This power divides people into rulers and subjects. It creates social stratification that gives some people authority of influence over others. This authority is the illegitimate influence that is acceptable by the people 
in question, who had subjected themselves to victimisation. Van der Ven (1996:297) has it right that 'In Charismatic authority leadership is acknowledged on the basis of exceptional or even extranatural or supernatural gifts attributed to it'. It is legitimately acceptable to conclude that the Charismatic authority is personal authority.

The theological understanding of authority that the NAR must comprehend is that the government of Christ's church must commence with the Lord Himself and His kingdom authority. He is the Head of the church; His rule is unique and incomparable. The church reflects the organic life of Christ's body made up of members who are dependent on one another in the exercise of the life they receive from Christ. It lives as an organism, not just as an organisation. The church is organised for service, not dominion. All government in the church is stewardship. Its leaders are servant-managers, who use their authority for the purpose of advancing the interests of those they represent and serve. This is captured by the Reformed theologian, Clowney (1995:202):

Christ exercises his absolute authority on behalf of his body, the church. His rule over the church differs from his rule over the universe, for it his saving rule: he frees his people from the power of the devil (Col 1:13-14). All authority in the church belongs to Christ. From his place of authority at God's right hand, Christ gives the keys to his kingdom; he validates in heaven what is done in his name on earth. Church government cannot modify his Word by deletion or addition (Rv 22:18-20; Gl 1:8, 12). Because its power is declarative, not legislative, it may not invent new doctrines or require practices that have no scriptural foundation.

The NAR, intentionally or out of theological apathy, has the tendency to perpetrate the modern abuse of ecclesiastical powers. Spiritual power can be more effective like physical abuse. The bottom line is that the church government should represent the authority (exousia) of Christ, the Kurios of the kosmos. There is organic mutuality that requires the joint exercise of church authority.

Although the NAR polity claims to be decentralised, the historical evidence is abundant that hierarchy and figurative persons had always accompanied its historical consortia. The Shepherding Movement of the 1970s and Bishop J L Payne's Christ Churches of God in Christ, USA International are good examples of this assertion. However, this is not always accompanied by successio apostolica as in the Roman Catholic or Eastern Orthodox traditions. Most of the modern day apostles and prophets claim to be the pneumatikoi, the special bearers of the Spirit. This is evident among those who practise glossolalia and prophecy, hence resorting to routinisation of charismata. The fivefold ministries should heed that the authority, should not be subjectively possessed, should not breed pride, but instead create a sense of accountability and humility. The biblically sound authority is a delegated authority, where leaders see themselves as ambassadors of Christ.

The church does not create its own leaders. Christ does. The gifts are not gifts made to people but gifts of people who have a particular role to play in the ecclesiastical life. The domata activities of Ephesians 4:11 are service to the body of Christ. They are the diverse manifestations of the Spirit in the community. These domata do not monopolise the Church's ministry. Their purpose is pros tonkatartismos (adjustment or equipment) and eisoikodomein - the perfecting and the building up of the body. This means house furnishing, mending or repairing of the saints. The doma's function is to help and direct the community so that members can perform their several ministries for the good of the whole. Although the particular domata refer to those who are in charge of guiding Christian community after the apostle's death, the passage assumes that all Christians are part of the building process. The focus of domata in this passage is the creation of new humanity created in Christ, guided towards maturity under Christ-appointed leadership.

The appreciation one can attach to the NAR is the worldview of the church's polity as that of simplicity and spontaneity. It is noteworthy to realise that the various types of Apostolic Churches have different types of authority occurring exclusively within their various church communities. This is the collegium, a free society, an association of equals who meet regularly in the oikos of one of its members. This was well demonstrated by the Shepherding Movement. On the other hand, 'the spontaneous structure is primarily based on the experiences, feelings, and attitudes that originate in the extraordinary charismata' (Van der Ven 1996:303). In this structure, embraced by the emerging apostolic church there is no what Weber (in Van der Ven) calls routinisation of charisma where charisma is institutionalised. The communion of the saints is a collegium where the priesthood of all believers is realised. The ecclesia vera is a Lebensform where there is hierarchia veritatum - the true church is living together in a hierarchy of truth.

\section{Wagner and phenomenological approach}

The critical reflection on this polity is that it is not exegetically correct. However, one has to remember Wagner's experiences and background. It must be noted that he confessed:

I want to make it clear that my research methodology is not philosophical or theological (in the classical sense) nor exegetical or revelational, but rather phenomenological. I am not saying that any of these methodologies is right or wrong. Phenomenology clearly is not superior exegesis. It is merely my personal choice (Wagner 2006:77).

A group of South African educationists give a synoptic view of the historical development of phenomenology as follows:

The word phenomenology was first used by the rationalist J.H. Lambert (1728-1777). I. Kant also used the term, while G. Hegel used it as a concept to describe a method whereby he departed from immediate information to penetrate to underlying knowledge. However, it is E. Husserl (1859-1938) who can be regarded as founder of phenomenology. Other contributors from different academic fields are M. Heidegger (1890-1976), who was also existentialist in his thinking. F. Brentano (1838-1917), D. Katz (1884-1953), M.J. Langeveld (b.1905) and M. MerleauPonty (1908-1961). In the United States, A. Giorgi is well-known 
and still active. In South Africa, C.K. Oberholzer, B.F Nel and W.A. Landman interpret phenomenology uniquely in the field of education. (Duminy et al. 1992:96)

Phenomenological school of thought maintains that in attempt for knowledge, the conscious is not involved in intentional data but is directed to things as they appear in reality. The British theologian, John Macquarrie's Principles of Christian Theology, uses this philosophy apologetically. He explains phenomenology as 'a methodology, a technique of description designed to provide a new inroad into philosophical problems'. He elaborates in justifying this philosophy by explaining it as a:

careful analytic description; or, to express the same idea in another way, it is letting us see that which shows itself (the phenomenon) by removing, as far as possible, concealments, distortions, and whatever else might prevent us from seeing the phenomenon as it actually gives itself. (Macquarrie 1971:20-31)

This is common in hermeneutical approach among the charismatic preachers. The biblical data must be accepted as it is. The core of interpretation is literal acceptance of what is written. Nothing must be explained from the metaphysical stance. This implies that all theoretical knowledge, assumptions, and beliefs should be put aside to allow the biblical data (phenomenon) to speak for itself and reveal its ultimate essence.

The data is collected and grouped together to make a unified fact. This is observed by the collection of different Bible verses to make a point, without a proper exposition or exegesis of the passages where these verses are derived, so that subjectivism could be eliminated, and the context verified. The Bible and the student are to be allowed to reveal their true nature and essence. In the phenomenological view, as practised by the charismatic teachers, the reader of the Scriptures lives intentionally within and in relation to the environment. The reader and the environment or contexts are interdependent. This implies that no fixed nature can be ascribed to a reader, hence the progressive revelation as embraced by the emerging apostolic churches. As the world of meanings changes, so God's revelation to His chosen ones changes. This opens a wide door of subjectivism in the way God communicates and reveals Himself.

The Charismatic theology agrees with phenomenology. Wagner (2004) tightens the screws in this regard:

The phenomenological approach leads me to employ terms not found in the Bible, because I believe it is not necessary to only use the Word of God but to also combine the Word of God with accurate observations of the present-day works of God. I am not approaching this so much from the question of what God ought to do as much as what God is actually doing. What the Spirit has said to the churches is one thing, but what the Spirit is now saying to the churches is another. (p. 77)

The NAR insists that the Holy Spirit is activating a restoration movement within the corporate Church of Jesus Christ today. This is a new thing that God is doing - to restore Christ's ascension gift ministry of the five offices. 'This is the beginning of the kingdom's order and structure given to the New Testament Church of this age. This is God's Government for Church's Leadership' (Payne 2004:34). In this context, to restore is to reactivate and re-establish something back to its original state and purpose. In the Charismatic context, restoration implies the sovereign act of the Holy Spirit within the Church to restore a biblical truth or ministry back to its proper order and function. It is a divine scheme in which God progressively restores truths to the Church. It is a belief that God is reviving His Church in this generation. The adherents view themselves as a Spirit-empowered church being restored to its New Testament glory. In the words of Moriarty (1992):

The new charismatics believe that in order for the church to experience New Testament results, it must recapture the New Testament pattern. This means the offices of apostle, prophet, evangelist, pastor, and teacher must be restored to equip the saints for the work of ministry. The church will not be as effective in the dominion process unless the fivefold ministry expounded in Eph 4:11 is restored and recognised by the church at large. For the body of Christ to come to full maturity, it needs to embrace all of the God-ordained ministries outlined in Eph 4:11; they are essential, not optional. (pp. 95-96)

The good news about Charismatic phenomenology is that Christians in this world are not-yet. People, especially Christians are beings who are not yet restored, but are still in that process. They are not yet walking, talking, or independent. God is busy fashioning them towards His likeness (maturity). As a result, they are striving to become someone Christ intended them to be; hence the insistent call to life of prayer and faith.

\section{Exegetical gaps in Wagner's interpretation of Ephesian passage}

\section{The timing of the letter of Ephesians}

The time of Paul's ministry in Ephesus ranges within 52 and $56 \mathrm{AD}$. The apostle spent almost 3 years in Ephesus heavily involved with interactions and confrontations: He encountered 12 disciples of John the Baptist (Ac 19:1-7). He engaged the Jews into debates in the synagogue for 3 months, demonstrating that Jesus is indeed the Messiah (Ac 19:8-10). Withdrawing from the synagogue he entered the lecture hall belonging to a man called Tyrannus where many Ephesians got converted (Ac 19:8-10). He performed many miracles as a means of persuading people about the gospel (Ac 19:11-17), and finally, there arose some commotion about him, instigated by a certain Demetrius (Ac 19:23-41)

All these events happened before the confirmation of elders in the Ephesians Church, long before the writing of the epistle, which were around $62 \mathrm{AD}$. At the time of the writing of the epistle to the Ephesians, church structure was already in place - the elders were already in charge of the church. The logic is evident that the church government under the elders were already functional by the time Paul mentioned the 
fivefold ministry in his epistle. The epistle was written to the pneumatic community that was already settled with full governance under the elders.

\section{Terminology in Ephesians 4:11-13}

The intention of domata in this passage is not for government, but for empowerment of the community. The apostolic intention is the preparation of God's people for works of service that will lead the community towards unity and maturity. Barth (1974) captures this fact:

Eph 4:11-13 is a locus classicus pointing out the coherence of the church's origin, order, and destiny. Certain ministries are given by Christ (vs. 11) in order that the church fulfils her present task (vs. 12), and, at the end, reach the goal set for her (vs. 13)... In following the teleological accent set by vs. 13, the treatment of the purpose described in vs. 12 will precede the description of the means mentioned in vs. 11. (p. 478)

The statement: 'to prepare God's people for works of service, so that the body of Christ may be built up...' (v. 12) has three elements. These three elements usher in the triple definition of the one purpose that determines the gift of the ministries mentioned in verses 7,8 , and 11 .

The equipment of the saints: The ministry here is katartismos, which according to Bromiley (1985:80); 'denotes equipment for the work of the ministry, while katartisis is the inner strength of the organic relationship of the community, or of the character of the members (2 Cor 13:9)'. The fundamental meaning here is that the domata of this passage is intended to restore to the original shape or position, to put in order, to realign, or to complete. The fivefold ministries are tasked to arrange or put into order everything in the church. They minister in order to reform or repair the weaknesses of the church. The wisdom of Lloyd-Jones (1984) reinforces this point:

Essentially this word means that we have to be made fit to serve the end and object aimed at. The picture is that something which we desire to use is not yet perfect, so we have to do certain things to it in order to fit it for that end and object for which we desire to use it. This means the supplying of certain deficiencies or the mending or adjusting of certain parts that are wrong. (p. 199)

It is all about community empowerment. It is the community development that involves the community itself in its own development - a notion that is reinforced further by LloydJones (1984) that:

the ultimate purpose of all these offices and divisions of labour in the church is the perfecting of the saints; and the way in which the saints are to be perfected is through the gift of the ministry, the function of which is to edify the body of Christ. There is an ultimate objective, and there are more immediate objectives. (p. 198)

The servant work: The 'grace gifts' given to community members are the same ministerial gifts given to Paul: But to each one of us, grace has been given as Christ apportioned it. This fact is reiterated by the apostolic juncture that: Surely you have heard about the administration of God's grace that was given to me for you ... I became a servant of this gospel by the gift of God's grace given me through the working of his power (Ephesians 3:2, 7). This grace, given to each community member, makes him an active servant. It does not come in vain, but makes a member of Christ's body work (1 Cor 15:10). It is clear that Ephesians 4:7 and 12 connect 'charismata' with servant work. The hermeneutical insight concludes that Ephesians 4:7's 'each' refers to all the members of the body of Christ as the recipients of 'charismata', not only apostles, prophets, evangelists pastors, or teachers. The same notion is carried on in $4: 13$ by 'we all', and is emphasised further by 4:16's 'each part'. This demonstrates the apostolic intention of the mutual contact of all members, not a specific group - in this case, the fivefold ministries.

The comparison of 1 Cor 12 and Eph 4 passages regarding 'grace gifts' shows that the Corinthians letter focuses on the unity of the community and the diversity of the functions within the community. On the other hand, the Ephesians letter stresses the building up of the body. The balance between the two passages indicates that the gifts are liberally distributed to each community member for service, not for governance as the fivefold ministries claim. Service and leadership are intertwined, though sometimes distinguished by those who garner for power to control instead of serving. Barth (1974) is correct:

Neither in 1 Corinthians nor in Ephesians are higher and lower, official and non-official, active and primarily receptive (or passive) church members distinguished as different ranks. On the contrary, in 1 Corinthians 12:22-23 the weakest members of the church are declared the most important. (p. 480)

The construction of the body of Christ: This function dismisses the parochial intentions in the community. All is done by Christ and for Him only. Bromiley (1985:39) alludes to the fact that the fivefold ministry's primary function is aletheia the true teaching or the revelation of authentic divine reality. They have something to say. They are engaged in the construction, the building of the body of Christ by speaking. They are men and women with diverse services to the internal edification of the community and the external expansion of the community. Their focus is the local and universal expansion of the ideals of the body of Christ. The construction of the body of Christ is not the job of the chosen few officers, it is the kaleo - divine calling of the entire community to strengthen and stretch itself. This is the crème de la crème - the very best of the church.

\section{The nature of the church at Ephesus}

Ephesians is closer to Romans, which is the crown and climax of Paul's Christology. It is the distilled essence, the obvious authoritative and the most consummate compendium of the Christian faith. This letter was written in $62 \mathrm{AD}$ after the establishment of many New Testament churches. This was the time when Paul had an opportunity to contemplate the meaning of the new phenomenon that had come into being. The reference to ecclesia in its diverse forms connotes the church universal rather than the local community. In its 
universal form, the ecclesia includes all who have believed in Christ since the inception of the community, and includes all who will yet believe before the realisation of the eschaton.

- The ecclesia is a mysterion - the mystery that has its meaning and essence hidden in Christ, though it is present where its members are found. The church as a mystery is prevalent in post-Vatican II ecclesiological commentaries. For instance, in the introductory statement, Avery Dulles (1987:9), in one of his famous books, Models of the Church states:

I wish to indicate my conviction that the Church, like other theological realities, is a mystery. Mysteries are realities of which we cannot speak directly. If we wish to talk about them at all we must draw on analogies afforded by our experience of the world. These analogies provide models. By attending to the analogies and utilising them as models, we can indirectly grow in our understanding of the Church.

The Church is a mystery that cannot be articulated in categorical terminology. It is mysterious because of the Christological and ecclesiological language used in referring to it (Ephesians 5:32). This is confirmed by the exemplification given by Clowney (1995) that:

The Bible certainly speaks of the church in heavenly terms. Chosen to holiness in Christ before the foundation of the world (Eph 1:4-5), it is not to be likened to the kingdoms of this world (Eph 1:23; 5:23, 32; Col 1:18; Jn 18:36). It is the dwelling of God, built of living stones on Christ as the chief cornerstone (Eph 2:20; 1 Pet 2:5). Only the Lord knows infallibly those who are his, and they are joined to him by the secret working of his Holy Spirit (2 Tim 2:19; Jn 3:8); (p. 108)

Because the church is the mystery, it needs domata such as the fivefold ministry in order to be energised towards the maturity.

- The ecclesia is an organism and organisation, with Christ as the Head. That it is an organism is confirmed by the twentieth century New Testament scholar, Robertson (1931:515); 'Ephesians chief stress is placed upon the Dignity of the Church as the Body of Christ the Head'. The church is permeated throughout all its parts with one common life. It has the same life for each member. Each member has not only been baptised into one Body, but has been made to drink into one Spirit (1 Cor 12:13). This implies that the church is something that is alive in the world and is organisationally constituted of all those in Christ universally. The Ephesians Church that received the epistle was organisationally rationalised and ratified, but still in its journey to be an organism. As an organisation, it was already under the leadership of elders, but as an organism, it still needed the fivefold ministry, not to govern but to strengthen towards unity and maturity. Kuiper (1998:115) echoes this sentiment that:

It was the practice of the apostles to form an ecclesiastical organisation wherever there was a group of believers. For instance, when Paul and Barnabas, on their way homeward from their first missionary journey, visited the various places where they had recently preached the gospel, they 'ordained them elders in every church'. (Ac 14:23)
The Ephesians received an epistle at the time when they were an organisation already, and organism in process. This made it imperative for them to learn about who they are in Christ, life of purity and unity, importance of striving towards the ideal of organisational unity on congregational and universal levels.

- The Ephesians church received the apostolic paradosis - the tradition that had to be transmitted as catechesis for ages and generations to come. The canonical function of the letter is to affirm the community members in their faith regardless of their ethnical or cultural background. The ecclesia is gifted to operate in diversity, and Ephesians are settled to operate in the like manner. They are the pneumatic community that is settled and is eschatological by nature. On its way towards maturity, they need to be strengthened for the journey and the task. The fivefold ministry is provided by Christ for this purpose of equipping the saints for this eschatological journey. It is the community led by the ecclesiastical governance of elders (Acts 20:13-38). They have passed the pioneering stage and are now settled, hence the need to maintain unity and grow towards maturity. Their missional task is dependent on their internal strength. Their apostolic and evangelistic endeavours depend on their prophetic, pastoral and didactic tasks.

- The Ephesians Church needed to be a charismatic fellowship. The internal dialogue of the epistle lacks the eschatological expectations. The eschatological terminology such as parousia, second advent, resurrection etc. is scantily evident in the letter. This indicates that the Ephesians community was settled and was over the turbulence of the last days' expectations. They were a fellowship that needed some energy to incarnate their faith in idolatrous environment in which they lived. They were expected to be the real communio sanctorum or congregatio sanctorum the Christian people who live in mutual concern for one another and mutual self-giving in the spirit of love. This notion was attested by the third article of the Barmen Theological Declaration and commented on by Moltmann (1985) that:

A community of brethren lives in the spirit of brotherliness, showing its fellowship with God's Son, 'the first-born among many brethren' (Rom 8.29), through a brotherly common life. ...The 'community of brethren' means the new, visible way of life... In the community of the brethren the greed for possessions and the claim to personal property come to an end... In the community of brethren social, cultural, racial and sexual privileges lose their validity...The community of brethren proclaims the kingdom of God through its way of life, which provides an alternative to the life of the world surrounding it (pp. 315-316).

This commentary carries weight in that it speaks of the rebirth of fellowship of Christians that is intertwined with friendship with Christ. Ephesians are exhorted to maintain the apostolic paradosis of the early years of the apostolic church, where Christians lived for each other and were sacrificing their possessions for each other. The communal lifestyle where charismata played a role in building up of the 
church was called into action. The essence of fellowship was and is expected to revolve around the grace gifts given to the community for the purpose of becoming more like Christ, the Head of the Church. The missional task is effective through charismatic lifestyle.

- The Ephesians Church was expected to be a self-developing community. The ecclesia is made up of the human beings who are in communion with the Trinitarian God. This composition rules out the idea of homo sans tete (human without mind). These members are creative individuals who attribute significance and survival in a temporal context. Their behaviour is not determined solely by external factors, but also by individuals' values, opinions, intentions and expectations. Ephesians 4:11-16 elaborates that the fivefold gifts are for the katartismos (equipping) of the saints for the work of the ministry. Each member is expected to be a martyrios - an active witness of the salvific acts of Christ here on earth. However each member needs to be trained for the witnessing service (Ephesians 4:11-12) by the gifted members in the community. In a nutshell, the expected outcome is that training for witnessing service is to be decentralised to the community rather than to the professors at the institutions of higher learning. This kind of training has its place and respect, but the maturity of the church should be from within by the members who share their gifts among themselves for the purpose of growth in all aspects:

The gift of apostleship along with other ministries thus serve to plant and water the seed of the Word so that it can bear fruit among the gifted congregation as all grow up to speak the Word to one another... The apostles belonged to the church as gifts to inspire and guide them as they grew to take their place as mature bearers of the Spirit and the Word themselves (Macchia 2006:236).

When 'grace gifts' operate in ecclesia, the energy is released and this becomes a resource for the local community to assert and strengthen itself. This confirms the sociological thesis that resources are all those elements in people's mental framework and total environment on which they depend for their existence and survival (Miller 1992:9). The resources are found to be within the people themselves. Charismata creatively unlock the vital energy, strength, talent, skills, knowledge and insight of a group or an individual. The revival fires would be set burning and spiritual energies released with spiritual vitality and soul-winning passion when the gifted members mould the character of those in their fellowship. This does not discredit the worthy scholarship as the emerging apostolic movement always retorts. Scholarship and spiritual passion can exist together within one person.

The purpose of domata in Ephesians 4 passage is to accomplish a specific task in a prescribed time: '... until we all reach unity in the faith and in the knowledge of the Son of God and become mature, attaining to the whole measure of the fullness of Christ' (Ephesians 4:13). This refers to the completion of the Body of Christ by adding to it all who are His elect people in this age. When the ecclesia is not self-developing, it stands vulnerable to the danger that is cautioned in the next verse: 'Then we will no longer be infants, tossed back and forth by the waves, and blown here and there by every wind of teaching and by the cunning and craftiness of men in their deceitful scheming' (Eph 4:14). The ecclesia, like the human body, is self-developing. Each member is expected to exercise gifts of grace spontaneously for the mutual building of the Body. In discussing the gift of prophecy which is part of the fivefold ministry, Wehrli (1992:51-52) emphasising the selfdeveloping concept of the church that is already settled, speaks of prophecy as:

God's gift to the church for its own life and leadership, and the gift of prophecy is one indication that the new age of the Spirit with its gifts (charismata) has already begun. These prophetic utterances in the community, which pointed to him for this special task, sustain Timothy in the face of hostility and persecution - that by them he might 'fight the good fight.' (1 $\operatorname{Tm} 6: 12)$

Ephesians 4:1-16 is an ecclesiastical exhortation. The first part of the passage is the description of the church's existence and order. The passage does not expound any self-contained and boisterous church or doctrine of the church. There is an urgent advice in Ephesians 4:1-3 for the members of ecclesia to be humble, united and strong in mutual love. The members are reminded of the creed of the church (Ephesians 4:4-6) that confesses the oneness which exerts a unifying force beyond the community of the saints. The confession is still called out and the one body (church) is still on the eschatological journey towards maturity. The one baptism is still a declaration that distinguishes the members from their former life. Ephesians 4:7-10 introduces the reader to the distribution of various gifts by the exalted Christ as a proof that Christ reigns supreme above all. The ministers given to the church in Ephesians 4:11 are charged to train fellow members for the ministry, and to prepare them for meeting the Lord, and protect them from immature and naïve behaviour (Ephesians 4:12-14). As ministers of Christ, they are mandated to ensure the growth of the church as attested by Forestell (1991:89), 'the continued existence and effectiveness of the church, like that of any other social group, requires the presence and activity of leaders, regardless of how these leaders may emerge from the group or of how they are installed and called to account by the group'. The accent is set upon the growth of the church towards the head, Christ Himself (Ephesians 4:15-16).

Because the epistle was destined for the settled pneumatic community, the ministers of Ephesians 4:11 were not intended for church governance, but for the empowerment of the community. The fivefold ministries are called to serve in a flat structured community where the priesthood of believers is displayed, not to create the hierarchy of leadership. Boff (1985) highlights the tone of the Ephesians church to be portraying the church as:

the encounter of the community of the faithful, an encounter prompted by Christ and the Spirit to celebrate, deepen faith, and to discuss the questions of the community in the light of the 
Gospel. Church... is more an event that may take place beneath an oak tree, in the house of some coordinator, or within a church building, rather than an institution with all of its goods, services, laws, doctrines, ministries, and historical continuity. (p. 155)

The ecclesia as the people of God maintains its cohesiveness and organised continuity of the faithful by allowing everyone to have a sense of belonging, and equality as a citizen of the kingdom. The mission of the church is not seen as a task entrusted to the selected few, but given to all though few are variably enabled to perform some extraordinary tasks. The Ephesians ecclesia is the organised people. Their organisation is only authentic if it has or allows some maximum benefit for all the members. As a community, the ecclesia displays equality whereby all members are baptised in the pneumatic Christ and anointed by the Holy Spirit. It is a democratic principle wherein the ecclesial power is derived from the sharing in the power of the Spirit and the ascended Christ active in the community. The Pauline notion is that there must not be a hierarchy in the settled community that will prevent the operation of charismata for its advancement. Christ released His domata to the church in order that she may strengthen herself towards her Head, Christ Himself. These gifts (domata) enhance the unity of the church and engross the sense of belonging because there is a maximum participation in the livelihood of the church.

\section{Secular models versus theological dictum}

The rudiments of leadership, though evasive in most of Wagner's works, are couched in Churchquake! (1999). Although Wagner perceives NAR as an extraordinary work of God ecclesiastically taking the cosmos by storm, the approaches and the methods are founded on secular business principles. He sees the NAR as a new wineskin required to contain the new wine of the Holy Spirit. The leaders are called to lead by casting visions for their churches with profit in mind. Profit is the driving force. The profit here is large following and financial explosion. Vision and values are intertwined. Vision casting is the top requirement and priority for apostolic leaders. 'An apostle's vision is based on the revelation he or she receives' (Wagner 2006:28).

Values centre on empowering and sending. The pastor is the businessman who leads the church with ideals of better returns. He or she has to be trusted unreservedly as an authoritative figure that can yield some desirable fruits. The pastor or the apostle is a Chief Operating Officer of the church, with the Board of Trustees (prophets, evangelists, teachers, etc.). Elders and deacons as per biblical teaching are unheard of in NAR. The title plays a critical role of distinction for respect.

\section{Conclusion}

There are positive contributions that Wagner had made to theology, especially in ecclesiology. His ecclesiology opened some numerous avenues for exegetical initiatives on some texts, especially the Ephesians 4:11-13 text. There have been some hermeneutical expositions to conscientise both the church and the preachers to derive and arrive at the biblically legitimate textual conclusions regarding the fivefold ministries.

Wagner's NAR ecclesiology is very missiological. It reminds ecclesia that her mission here on earth is not yet complete. All fivefold ministries are of conviction that church planting, especially translocally is the mark of apostleship. These apostles' essential call is to 'plant new churches as they reflect the intent of their sender, Jesus Christ' (Myer 2006:180). The NAR emphasises both the information and transformation; and that those transformed must penetrate new territories. 'This means blasing a trail both geographically and spiritually; entering areas where the gospel has not gone before and engaging the enemy in his own camp' (Stone 1999:40). These gifts in Ephesians passage are not for parochial benefit, 'but are important and necessary to perfect the saints and help fulfil the Great Commission' (Eckhardt 1999:48).

The other positive contribution the NAR has made to ecclesiology is the need and importance of training church leaders. Wagner is very strong on training and equipping for spiritual warfare and for ecclesiastical responsibilities. This is one of the missing dimensions in Pentecostal and Charismatic ecclesiology. People are called without preparation and training. Though NAR does not recognise or recommend formal theological training in established institutions, they are of the opinion that formally and inspirationally those sent out should be equipped. One of the apostolic leaders, Bill Hamon captures this that 'apostles were called and ordained by Christ Jesus to function here on earth, from the time He chose the Twelve and called them apostles until He comes again at the end of the age of His mortal Church' (1999:66). There is therefore now no need for formal calling as this is already ordained by Christ Himself.

It cannot be downplayed that Wagner also conscientised today's theology to the reality of the existence of demonic activities operating against any Christ's cause. This has elevated, and rightly so, the importance of prayer in pioneering and church expansion. The rubrics might be questionable, but the fundamental importance of prayer is reckoned with. The Church was since the entrance of this debate of demoniacs; re-examined demonology as a theological dogma. Hamon (1999:66) concludes that after catching this new wave's reality, the church's response is either persecution, passiveness, or propagation. Studies on demonology assist in opting for one of the three options. This leads to conclusion of either embracing Wagner's ecclesiology, or rejecting it as the Church in the last days.

\section{Acknowledgements Competing interests}

The author declares that he has no financial or personal relationships which may have inappropriately influenced him in writing this article. 


\section{References}

Avis, P., 1992, Authority, leadership and conflict in the Church, Trinity Press International, Philadelphia, PA.

Barth, M., 1974, Ephesians 4-6: A new translation with introduction and commentary Doubleday, New York.

Boff, L. 1985. Church: Charism and Power. Liberation Theology and the Institutional Church, Crossroads, New York.

Bromiley, G.W., 1985, Theological dictionary of the New Testament. (Abridged in One Volume), W B Eerdmans Publishing Co, Grand Rapids, MI.

Clowney, E.P., 1995, The Church: Contours of Christian theology, Intervarsity, Downs Grove, IL.

Dulles Avery S.J., 1987, Models of the Church (Expanded Edition), Doubleday, New York.

Duminy, P.A. Dreyer, H.J \& Steyn, P.D.G., 1992, Education for the student teacher 3, Maskew Miller Longman, Cape Town.

Eckhardt, J., 1999, Moving in the Apostolic: God's plan to lead his Church to the final victory, Regal Books, Ventura, CA.

Forestell, J.T. 1991. As Ministers of Christ: The Christological Dimension of Ministry in the New Testament, Paulist Press, New York.

Hamon, B., 1999, Prophets and the prophetic movement: God's prophetic move today, Destiny Image Publishers, Santa Rosha Beach, FL.

Kraft, C.H., 2000, I give you authority, Monarch Books, London.

Kreitzer, L., 1997, The epistle to the Ephesians, Epworth Press, Peterborough.

Kuiper, R.B., 1998, The Glorious body of Christ, The Banner of Truth Trust, Edinburgh.

Lloyd-Jones, M., 1984, Christian unity: An exposition of Ephesians 4:1 to 16, Bake Book House, Grand Rapids, MI.

Macchia, F.D., 2006, Baptized in the spirit: A global Pentecostal theology, Zondervan Publishing House, Grand Rapids, MI.

Macquarrie, J., 1971, Principles of Christian theology (Study Edition), SCM Press, London.

Miller, G.T., 1992, Living in the environment: An introduction to environmental science, 7th ed., Wadsworth Publishing Company, Belmont, CA.

Moltmann, J., 1977, The Church in the power of the spirit, SCM Press, London.

Moriarty, M.G., 1992, The New Charismatic's, Zondervan Publishing House, Grand Rapids, MI.
Myer, R., 2006, Fivefold ministry made practical: How to release apostles, prophets, evangelists, pastors and teachers to E quip today's Church, House to House evangelists, pastors a
Publications, Lititz, PA.

Payne, J.L., 2004, The Five ministries: A New Testament Church's study on the 5-Fold ministry, Church House Publisher, Jackson, MS

Robertson, A.T., 1931, Word pictures in the New Testament, Vol IV. The Epistles of Paul, Broadman Press, Nashville, TN.

Stone, D., 1999, Gifts from the Ascended Christ: Restoring the place of the 5-Fold ministry, Treasure House/Destiny Image \& Publishers, Shippensburg, PA.

Van der Ven, J., 1996, Ecclesiology in context, W.B. Eerdmans, Grand Rapids, MI.

Wagner, C.P., 1991, Engaging the enemy: How to fight and defeat territorial spirits, Regal Books, Ventura, CA

Wagner, C.P., 1994/2005, Your spiritual gifts can help your Church grow, Regal Books, Ventura, CA.

Wagner, C.P., 1996, Confronting the powers: How the New Testament Church experienced the power of strategic-level spiritual warfare, Regal Books, experienced
Ventura, $\mathrm{CA}$.

Wagner, C.P., 1998, The new Apostolic Churches, Regal Books, Ventura, CA

Wagner, C.P., 1999, Churchquake!, Regal Books, Ventura, CA.

Wagner, C.P., 2000, Renewal Journal \#15, The New Apostolic Reformation. Createspace Independent Publishers, Ventura.

Wagner, C.P., 2001, Hard-Core Idolatry: Facing the facts, Regal Books, Ventura, CA.

Wagner, C.P., 2004, Changing Church, Regal Books, Ventura, CA.

Wagner, C.P., 2006, Apostles today, Regal Books, Ventura, CA.

Wagner, C.P., 2011,'The New Apostolic Reformation Is Not a Cult', Charisma News. http://www.charismanews.com/opinion/31851-the-new-apostolic-reformationis-not-a-cult, Viewed on 13 October 2015

Wagner, C.P. 2013. This Changes Everything: How God Can Transform Your Mind and Change Your Life, Regal Books, Ventura.

Wehrli, E.S., 1992, Gifted by their spirit: Leadership roles in the New Testament, Pilgrim Press, Cleveland, $\mathrm{OH}$.

Wilder, F., 2011a, 'Rick Perry's Army of God', The Texas Observer, 3 August, viewed 26 October 2015, from http://www.rightwingwatch.org/content/rick-perrypartners-radical-apostle-c-peter-wagner-response-prayer-rally

Wilder, F., 2011b, 'As Texas Gov. Rick Perry Enters GOP Race, New Exposé Reveals His close ties to Radical Evangelicals', Democracy Now 12 August, viewed 14 October 2015, from http://www.democracynow.org/gifts/dvds-cds/shows/2011/8/12. Viewed 16 October 2015 